\title{
THE BOOK IN ITS TIME
}

Michael Joyce ${ }^{*}$

\begin{abstract}
Originally written as an invited presentation for Feira Nordestina do Livro in Recife, but not presented there when funding fell through, this essay considers three entangled senses of the book in its time-historical, presentational, and experiential- considering the book as a vehicle in which "time is articulated and re-synchronized through various material practices." As a result of having written about the book, especially in relation to new technologies and digital media, for over a quarter of a century, this essay is to some extent haunted by past formulations of these questions. In speculating about the future of the book, the essay begins from the premise that the future of some things is to be more like themselves, that is, self-similar, but then proceeds to a parable that reflects the life of most books since the dawn of the age of print in which some circulate and disappear from use, others are treasured for reasons of art, of literary, historical, or practical value, still others are kept as a hedge against time or otherwise move through generations of this world, fading and renewed, forgotten and remembered by turns.
\end{abstract}

KEYWORDS: Digital Text. Temporality. Subjunctivity. Self-similarity. Incorporation.

The mystics and the poets speak of the future as all we have of time. For them the past ever disappears into a succession of presents, none of which last; and we are left with only the future to tell us what we have been, what has happened to us, what we have done, what we wished, where we thought we were going. In this belief the mystics are joined in our time by the cognitivists, neurophysiologists, futurists, and technologists, as well as various sects of fundamentalists. The book in its time mimicked the succession of present time, the past palpably passing from the right to the left hand as we read until the block of pages remaining thinned to nothing but the blank endpapers of the unfathomable future.

The poet, novelist, and mystic Fanny Howe writes of "the way time runs ahead of us, while we seem, as humans, to be discarded by a future that is chasing us in

\footnotetext{
*Vassar College, Poughkeepsie, New York, United States of America. E-mail: mijoyce@vassar.edu$$
\text { (c) BY-NC-ND }
$$

Esta obra está licenciada com uma licença Creative Commons. 
the form of the past" (HOWE, 2003, p. 30). To contemplate "the book of the future, the future of the book," it is natural that we may feel ourselves haunted by past lives, our own and those of the book.

For over a quarter of a century, my writing has focused upon the book, especially in relation to new technologies and new media; it is thus natural that my consideration will to some extent be haunted by my past formulations questioning it. In November, I will begin my eighth decade on this earth, and so my interest in futures may seem especially laden. In my speculations, to quote the cybertheorist Gregory Ulmer, "The time of my haunts is measured by 'saudade' - the samba feeling" (WALKER and ULMER, 1997, n.p.). But the truth is, as an Irish-American and Roman Catholic poet and writer, I came by my sense of Fado honestly, at an early age, and by a different name, perhaps Providence.

In English, although I do not know if this is also true in Portuguese, the phrase "the book in its time" admits to an ambiguity. On the one hand it suggests a historical account of something whose time has past. For example one might say, "The book in its time was the preeminent form of human knowledge and imagination." But the phrase can also refer to the way the book presents knowledge and imagination temporally and progressively, where one might say, "The book in its time offers a sense of confinement and expanse alike that is distinct from other forms of human expression."

There is even a third sense of the phrase - closely related to the second - in which one might refer to a special experience of time, perhaps most familiar to us from stories, and especially fairy tales, but which arguably extends outside the realm of imagination, or rather to the special kind of imagination we have come to understand as science in a quantum age.

Before exploring each of these three senses of the book in its time, we must linger in three magical accounts of time and the future; the first from Fanny Howe's aforementioned memoir, the second from a novel, and the third from a 
philosophical treatise on quantum physics, all texts, coincidentally or not, written by women.

In illo tempore (the Portuguese Era uma vez... or the English "Once upon a time...") is the formula for fairy tales, and indeed Fanny Howe's preceding quote comes from a chapter on fairies in a book of what she calls "Meditations on Word and Life," The Wedding Dress. There the full of what I quoted before goes as follows:

\begin{abstract}
Something about time is involved in the existence of fairies, the way time runs ahead of us, while we seem, as humans, to be discarded by a future that is chasing us in the form of the past. Into all of this drops the tale. In fact the controlling mechanism at work in writing - that is, the effort of stabilizing time... generates fiction (HOWE, 2003, p. 30).
\end{abstract}

Roderigo S.M., the deeply untrustworthy, deeply troubled narrator of Clarice Lispector's great modernist fairytale, A hora da estrela (The Hour of the Star), early on tells us that he is writing: a "story that is patently open and explicit yet holds certain secrets - starting with one of the book's titles 'As For The Future', preceded and followed by a full stop" (LISPECTOR, 1986, p. 13). The latter he tells us is a marker whose "need for confinement will ultimately become clear" (LISPECTOR, 1986, p. 13). As indeed it does in the last words of the novel's simple, saintly, countrywoman heroine Macabéa, who has just come from visiting a psychic who, Roderigo tells us, offers her a glimpse of an ambiguous future whose promised happiness is instead an anguish. She leaves the psychic he tells us "pregnant with the future, [feeling] inside her a hope more violent than any despair she had ever felt" and almost immediately steps off the curb into the path of an oncoming Mercedes (LISPECTOR, 1986, p. 70). Lying in the street, dying, she speaks her last words, "As For The Future-" she says but does not finish the thought, at least in this world (LISPECTOR, 1986, p. 75). Roderigo tells us, "She wanted to vomit something that wasn't her body, to vomit something luminous. A thousand-pointed star" (LISPECTOR, 1986, p. 75). 
What he imagines is that, pregnant with the future, she has performed a perverse birth, an inversion of time, although I would suggest rather that Macabéa's is a version of time much more in concert with our deepest experience of it, our sense that each of us in fact forms time, and therefore that we also form the future.

In an interview whose title, "Matter feels, converses, suffers, desires, yearns and remembers" beautifully quotes its interviewee, the theoretical physicist, feminist, and philosopher Karen Barad; she describes a classic experiment in quantum particle physics involving the passage of a rubidium atom in an excited state through either of two micromaser cavities wherein

\begin{abstract}
We assume that time is a given externality, just a parameter that marches forward, and that the past already happened and the present, that moment "now" just slipped away into the past, and that the future is yet to come. But if we examine this [experiment] carefully... what we are seeing here is that time is not given, it is not universally given, but rather that time is articulated and resynchronized through various material practices. In other words, just like position, momentum, wave and particle, time itself only makes sense in the context of particular phenomena. So what is going on here is that physicists are actually making time in marking time, and that there is a certain way in which what we take to be the "past" and what we take to be the "present" and the "future" are entangled with one another (BARAD, 2009, n.p.).
\end{abstract}

Let us begin then to consider all three entangled senses of the book in its timehistorical, presentational, and experiential- considering the book as a vehicle in which "time is articulated and re-synchronized through various material practices" in the way Barad speaks of (BARAD, 2009, n.p.). In beginning with the historical sense of the book in its time, I recall my own history of attempts to situate the book at the dawn of digital literature under the injunction of Jacques Derrida, who way back in 1972 in an essay entitled "Hors Livre" (outside/before the book), prophetically wrote that

While the form of the "book" is now going through a period of general upheaval, and while that form now appears less natural, and its history less transparent, than ever, and while one cannot tamper with it without disturbing everything else, the book form alone can no longer settle ... the case of those writing 
processes which, in practically questioning that form, must also dismantle it (DERRIDA, 1981, p. 3).

In 1990, I gave the keynote talk at the Sixth Computers and Writing Conference in Austin, Texas where- with tongue partially in cheekiness - I announced, "The time of the book has passed. The book is an obscure pleasure like the opera or cigarettes. The book is dead, long live the book" (JOYCE, 1995, p. 97). I apparently liked this formulation so much that I included it again one year afterward in the second issue of arguably the earliest online scholarly journal about digital theory, Postmodern Culture. I was a young man then and young men like to quote themselves, especially young men giddy with the possibilities of what in my book of essays about hypertext, Of Two Minds, I called nomadic texts whose movement from one place or form to another is "made effortless by the electronic medium that makes it easy to cross borders (or erase them) with the swipe of a mouse, carrying as much of the world as you will on the etched arrow of light that makes up a cursor" (JOYCE, 1995, p. 3).

Like many young men also, I'm not sure that I knew then quite what I was talking about, but as the years went on - as older men are wont to- I came to think that it was surprisingly wise, even prescient, nonetheless. When I did not know what I was talking about I suppose I had thought to put the book in a category of things that, although their centrality and popularity has passed, remain ardently loved by those who treasure them. I had quit smoking two years before but knew that if I took one puff again, I would smoke forever. I had never been a devotee of opera but those devotees I knew were as fervent as smokers about their pastime, and likely to die off long before opera did.

What I came to think was that the book, like the cigarette or an opera, is not so much a pastime as it is an incorporation of time, a renewable, even cyclic, experience of temporal incorporation, which, in Barad's words, is "actually making time in marking time" (BARAD, 2009, n.p.). (Marking Time - coincidentally, and still speaking of young men-was the title of my first, unpublished novel.) 
In my techno-prophetic manifestos I had perhaps too glibly characterized print as a "wood pulp fetish," as well as attributed a nostalgic sentimentality for the way a book fits (or did then) in the seatback of an airplane, in a way that momentarily blinded my understanding of the half-life of a book (JOYCE, 2000, p. 88). What the book as wood pulp shares with other carbon-based creation such as human flesh in fact links it as securely as a hypertext link to our everyday sense of mortality; while the book's ability (and suitability) as what the French call a dispositive, a private and portable apparatus for making time in marking time, links it to our experience of space and passage in airplanes or otherwise.

Some five years afterward, in 1996 - at a meeting fortuitously named "The Future of the Book," convened by Umberto Eco in San Marino- I gave a talk called "(Re)placing the author: "A book in the ruins," whose subtitle quoted the title of a poem by Czeslaw Milosz, a close-reading of which formed my core argument. The talk featured a recurrent phrase, "Print stays itself, electronic text replaces itself," which-perhaps because I, like Milosz, was raised a Catholic and conscious of being not far from the precincts of Rome- functioned like the recurrent responses of a litany (JOYCE, 1995, p. 232). Perhaps because I was a little older in this lecture, I was more attuned to history and a little more aware of-if no less enthusiastic about- how electronic text (a term I then preferred to the digital) puts us at a remove from our mortal experience of space and passage. "Print stays itself, electronic text replaces itself," I invoked my mantra, and continued

\footnotetext{
Electronic text is as apt to evolve before it forms, as apt to dissolve before it finishes. On the screen it takes our constant and attentive interaction to maintain even the simulacrum of static text. The future, too, requires as much of us, and has for some time.... The future won't stay still but instead keeps on replacing itself. The page becomes the screen, the screen replaces the page. We could call this placement "history." Electronic texts present themselves in the medium of their dissolution: they are read where they are written, they are written where they are read (JOYCE, 1996, p. 273-274).
}

Lastly, some four years afterward in 2000, I was invited to give the annual Adam Helms Lecture, sponsored by the Swedish Publishers' Association and Stockholm University Library. In giving that talk, "A web of caring: the book as it was to us," I 
became more cognizant of the loss attendant to the dissolution of time and space in the recurring and endlessly rewritten surface of digital texts. "Time and space exist for us above the same plane and under the same sky," I wrote, "The book as it was to us is the place of the time of our caring...Yet, in time, the time of the reader, all which is carefully built up falls back into flux... The patina of time as time is mortality, read on the body, in the body, in a web of caring, for which the book has stood us in good stead and now the electronic text must likewise" (JOYCE, 2001, p. 6-28).

While keeping in mind the mortal patina of time, we consider the second sense of the book in its time, the distinctive way it presents knowledge and imagination temporally and progressively. As I previously suggested, as opposed to the flux of the digital, the book in its time - that is, both the way it presents time to us and how we experience it in the time of our reading - offers a sense of confinement and expanse alike distinct from other forms of human expression. Perhaps its primary means of doing so is to call language itself into question. Not language in some general sense but the actual language before us on the page. Print may not replace itself in the way of electronic text but in staying itself it introduces a temporal ambiguity within us.

With book in hand, we are led to wonder if what we see means what we think it does while the pure confinement of the book's form leaves us with at least the illusion that we must determine our understandings within the boundaries of its span. Unlike ebooks, we cannot click somewhere to instantly settle our confusions, illuminate forms or contexts, or link to backgrounds, histories, biographies, etymologies or grammars. Nor for that matter can a click distract us from endowing what we see with entirely another meaning than the words apparently have. To be sure we can put the book down and consult another book or person or even a computer, but in doing so we become vividly aware that we move outside the time of the book as meanwhile it patiently awaits our inexorable return or remove with equanimity. All of which is to say that the book mimics our mortality; it lasts as long as we do. 
Si près, a book by Hélène Cixous takes the form of a memoir and meditation seemingly stemming from a scene between Cixous and her mother, an encounter stirring the memory of a particular sentence spoken to the latter. The character, je-whom one takes to be Cixous herself- finds herself saying to herself and to her mother, j'irais peut-être à Alger, perhaps I might go to Algiers, the country of her birth, her mother's birth, and significantly of her recently deceased, dearest friend Jacques Derrida's birth as well. Irais, I might go, the verb made clearly conditional on the page with its last letter $s$, is to the ear identical to the future, irai, I will go. The reader is left to adjudicate a difference between the language seen and whatever sounds and other senses haunt it. (Here one might note in passing that the English translator, Peggy Kamuf, specifies that a like haunting is lost in the English title for the book where "So close cannot close the gap in meaning that a French speaker easily detects in Si près, where the name of the cypress tree, cyprès," a figure of the characters' cherished memories of Algeria, "can also be heard") (KAMUF, 2009, p. 163).

Even if we feel perfectly certain of the meaning of a word or phrase that we have read in a printed book, it often happens that later in our reading we can only half recall what exactly it was and we are left either to page through the text looking for it or, if we are lucky, where we've marked or dog-eared it, or simply to allow whatever possibilities which come to mind serve as a substitute for what we think we have read.

The question facing the character to whom Cixous has given her name and history in Si pres resides in how one parses the sentence that has come into her mind and that can signify either possibility or volition, j'irais peut-être à Alger. Its parsing forms the narrative line of what follows, a meditation on mind, mortality, motherhood, and motherland couched in what she may want to say is exemplified by the unconscious occurrence of an improbable sentence. There is the story here, and the story that there is, to quote Fanny Howe again, evolves in "the effort of stabilizing time [that] generates fiction" (HOWE, 2003, p. 30). 
The book is not alone in being a vehicle for stabilizing time, but it does so in a way unlike subsequent technologies of the word. Six years before his own death, and nearly a decade before Cixous's book, Derrida in the epilogue of Monolingualism of the Other (a book that famously begins with the sentence "I only have one language; it is not mine.") describes the project of writing about his own Algeria in a surprising, albeit characteristic $20^{\text {th }}$ century metaphor (DERRIDA, 1998, p. 1). "What I am sketching here is...rather than an exposition of myself... is an account of what will have placed an obstacle in the way of this auto-exposition for me. An account, therefore, of what will have exposed me to that obstacle and thrown me against it. Of a serious traffic accident about which I never cease thinking" (DERRIDA, 1998, p. 70).

The printed book is that traffic accident in Derrida's punning auto-exposition, a sensation of constantly being thrown against ourselves and the language of the other, about which we never cease thinking. It may be understandable that I am fascinated by this metaphor of Derrida's since my best-known work, the hypertext, afternoon, a story, is about a character who never ceases thinking of a traffic accident that he may or may not have seen. My character begins his tale with a common locution in English, which some readers nonetheless find frightening in this context: "I want to say I may have seen my son die" (JOYCE, 1987, n.p.). The ambiguous gap of meaning in this sentence- where "want" can signify a thing either missing or desired - as a narrative stratagem owes itself to the fundamental subjunctivity of the book. The hypertext possibilities build upon the inherent possibilities of the word as it finds itself fixed on page or screen alike and yet plays through multiple possibilities in the mind.

I would go so far as to say that all books proceed under the sign of the subjunctive. Books close in upon themselves as if to inhabit the gap between possibility and volition - wish and will- as well as between what is missing or desired. Poems, of course, have dwelled in this gap, certainly long before print, and in fact long before written language. They exploit the haunted, echoic quality of all language, 
and even in the shortest lyrics - say the Quadras Ao Gosta Popular (Quatrains in the Popular Style) of Pessoa- one is constantly aware that poems perch to sing their songs in the tentativeness of the subjunctive. This is why, I think, they always seem uncomfortable on the screen whose very surface is the wind that sways the branches.

This brings us to the third sense of the book in its time as a special experience of temporality that arguably extends outside the realm of imagination. While my discussion thus far has centered upon literary works, I would suggest that something of the same subjunctive sense operates in our contemporary, network age reading of printed non-fiction books. Indeed I suspect this is more and more the case as digital forms make us increasingly suspect of the infinitesimal half-life of any factual, discursive, or expository texts in print in the face of the seemingly infinite proliferation of digital information. We are more aware than ever of such books' ephemeral qualities and more apt to read them with almost a fiction reader's interest in how a certain mode of thinking came to be, rather than for its outcomes, veridicality, or current applicability. All such books become historical, psychological, speculative, or philosophical; or rather we become aware of how much they always were so. They present themselves as evidences of processes rather than settled questions. The once upon a time or Era uma vez explicit in stories, which had become implicit and transparent in the apparent authority of printed factuality, returns again into view.

In turning now from the future of the book to the book of the future, we must ask ourselves whether the printed book continues to offer a particular and irreplaceable kind of what technologists and media theorists call an affordance, that is "the qualities or properties of an object that define its possible uses or make clear how it can or should be used" (NORMAN, 1988, p. 9).

Fifteen years ago when the vice president for computing and information services at Vassar College asked a number of us to suggest directions for the next decade; I simply said the cellphone. "No seriously," the vice president asked. "Seriously," I 
said. She laughed. My reply was not especially prophetic, since anyone attending carefully to developments in the links between telephones and computers could have seen what was coming, although not, I confess, that people would be willing to carry around a pad phone bigger than a slice of picanha.

That said, I am only as much a futurist as any novelist or poet, albeit in my case one who is also a media scholar and practitioner. My speculations begin from the premise that the future of some things is to be more like themselves, that is, selfsimilar. When we think of new technologies we often see them as what my longtime friend and sometimes collaborator, Jay David Bolter, famously termed remediation, where any new technology simultaneously and paradoxically seeks to show itself as both changing everything about prior forms and scrupulously encompassing and representing them (BOLTER, 2009, n.p.). Or- in what is much the same thing under a different cultural and commercial franchise- we imagine that technologies, and especially media, will continue to converge. It is under this dispensation that the cell phone already houses not just the book but the radio, the television, and the heart monitor, as well as the controls for the home heating system, for the refrigerator, for the vacuum cleaner, and for a flock of pet drones circling overhead like forlorn geese.

On the face of it, the book is increasingly used as an expendable entity closer to a plastic water bottle than a dark bottle of fine wine to be cellared or savored. Like plastic water bottles, books seem to bob in great artificial islands amidst oceans swarming with other remnants of lost cultures. With the utter consolidation of mainline publishing and the distribution monopoly of (not your beloved river but the corporate creature) Amazon, the book has taken on an interesting currency. Increasing numbers of deaccessioned library copies and other used bookstore surplus appears for nominal prices as low as one penny albeit with shipping and handling fees that must incorporate profit. These often include books that have been published in recent months, especially review copies, which reviewers' assistants weekly if not daily cart to used-book stores by the wheelbarrow or carton. 
Meanwhile small presses and online just-in-time self-publishing options have made both low cost ebook and print publication almost universally available, although for a book to gain notice and readership requires publicity and good design both of which raise the human cost and capitalization required to reach readers beyond a small circle. For these reasons the stories of online ebooks that have gone viral and have been acquired by major publishers for millions of dollars are, like all such myths, accounts of rare creatures meant to keep the rest of us contained in our dreams.

If we venture to imagine a future for the book which does not involve its becoming even more like itself, even more self-similar, we bang squarely against the ocularcentrism of the book in both its traditional and digital forms. Print still calls us, as it did from the first, to imagine spectres from the formulation of letters on a page just as truly as a musical score calls us to hear the music of the spheres or our inner being alike. What the media scholar W.J. T. Mitchell, following Gottfried Boehm, calls the pictorial turn-the way we increasingly construct our reality through pictures—only accents and augments books' ocularcentrism (BOEHM and MITCHELL, 2010, n.p.).

Ted Nelson, who invented the term hypertext in the 1960's at the same time coined the term teledildonics for what has become the dream of pornographers and so-called libertines everywhere, that is a system of distant ecstasy controlled by computers. So, too, perhaps the book could offer its own more or less discreet ecstasies. As an antidote to ocularcentrism, we might imagine that a book function would one day be implanted via microchips under the skin as a prosthesis of the sort not just imagined but pioneered by the great Brazilian-American transgenic artist, Eduardo Kac. Instead of the eye, such a book function could proprioceptively inhabit the very surface or depth of our bodies in a way as readable as Braille is to the blind. 
More likely though, as "the cloud" moves from being a metaphor for the ubiquitous network of computer storage and servers in some imaginary wonderland into something we imagine floating above us as real and as proximate as any part of the natural world, our bookishness may give itself over into special instances of cyborgized affiliation with the world as we perceive it. Some may pin their hopes on augmented realities, which will rain down from the cloud to brighten, paint, and fill the world with melodies and memories as it already does for the poet, the painter, the mystic, the madman and the child.

In modest and experimental closing, imagine that future books undergo a simple alteration, one that does not change their nature as objects save for two technological interventions: the first being a fingerprint recognition sensor of the sort used in security portals or cell phones embedded into their covers, and the second being a special kind of ink controlled by these sensors.

The ink would make the text and any figures or images visible to the book's owners as soon as they registered their fingerprint and thereafter every time they took the book up into their hands. The ink would never fade for the owner. Owners could designate one heir to whom they could bequeath the book by a simple transfer of fingerprints. For those who inherit the original book the ink would also remain crisp and unfading.

However each time the book was transferred to someone else, either by the original owner or by the single heir bequeathed the book, the ink would incrementally fade so that over a certain number of transactions- let us pick the conventional magic number of fairytales and say seven - its text and images would disappear. (In order to avoid nitpicking a futurist fantasy, let us stipulate that there would be special versions for libraries and bookstores, perhaps with RFID sensors that allow a book to be read in a certain restricted geographical location.)

The result of such an innovation would be that some books would circulate widely for a time and then die a quiet life while others would be treasured for two full 
generations before being subject to the same gradual death as the first. Almost surely some of those books that were fated to disappear would be rescued by being recopied and republished by caretakers of one sort or another, whether for spiritual, historical, philosophical, or purely personal reasons. Such books would reenter into the life cycle of repeated transactions and generational care.

What should be obvious is that this parable in fact reflects the life of most books since the dawn of the age of print. Some books circulate and disappear from use, others are treasured for reasons of art, of literary, historical, or practical value, still

others are kept as a hedge against time or lodge themselves in quiet places away from the bustle of the everyday world to be discovered long after not just their authors lives but likewise the lives of the rest of us who likewise move through generations of this world, fading and renewed, forgotten and remembered by turns.

\section{Works Cited}

BARAD, Karen. "'Matter Feels, Converses, Suffers, Desires, Yearns and Remembers"." Rick Dolphijn and Iris Van Der Tuin. New Materialism: Interviews \& Cartographies. Ann Arbor: U of Michigan, 2012.

BOEHM, Gottfried, and W. J. T. Mitchell. "Pictorial versus Iconic Turn: Two Letters." The Pictorial Turn. By Neal Curtis. London: Routledge, 2010.

BOLTER, Jay David., and Richard Grusin. Remediation: Understanding New Media. Cambridge, Mass: MIT, 2000.

CIXOUS, Hélène, and Peggy Kamuf. So Close. Cambridge: Polity, 2009.

DERRIDA, Jacques. Dissemination. Trans. Barbara Johnson. Chicago: U, 1981. 
DERRIDA, Jacques. Monolingualism of the Other, Or, The Prosthesis of Origin. Stanford, CA: Stanford UP, 1998.

HOWE, Fanny. The Wedding Dress: Meditations on Word and Life. Berkeley: U of California, 2003.

JOYCE, Michael. Of Two Minds: Hypertext Pedagogy and Poetics. Ann Arbor: U of Michigan, 1995.

JOYCE, Michael. "(Re)placing the Author: "A Book in the Ruins"' The Future of the Book. By Geoffrey Nunberg. Berkeley: U of California, 1996.

JOYCE, Michael. Afternoon, a Story. Watertown, MA: Eastgate Systems, 1987. Republished Eastgate 1990.

JOYCE, Michael. A Web of Caring: The Book as It Was to Us. Stockholm: Svenska Förläggarefören., 2001.

JOYCE, Michael. Othermindedness: The Emergence of Network Culture. Ann Arbor: U of Michigan, 2000.

LISPECTOR, Clarice. The Hour of the Star. Manchester: Carcanet, 1986.

NORMAN, Donald A. The Psychology of Everyday Things. New York: Basic, 1988.

WALKER, L.M. and ULMER, Gregory L. "Wishing." alt-x. 1997.

Recebido em: 09/11/2015.

Aceito em: 11/12/2015. 